\title{
Construct validity of Croatian version of the Pavlovian Temperament Survey (PTS)
}

\author{
Sanja Tatalović Vorkapić* ${ }^{* 1}$, Ivana Lučev² and Meri Tadinac ${ }^{3}$ \\ ${ }^{1}$ Faculty of Teacher Education, Department of Preschool Education, Rijeka, Croatia \\ ${ }^{2}$ Institute for Migration and Ethnic Studies, Zagreb, Croatia \\ ${ }^{3}$ Department of Psychology, University of Zagreb Faculty of Humanities and Social Science, Zagreb, Croatia
}

\begin{abstract}
The aim of this study was to examine the construct validity of Pavlovian Temperament Survey (PTS) by determining the relationship between three Strelau's dimensions of temperament (strength of excitation, strength of inhibition, mobility) and basic dimensions of personality as were defined by Eysenck and in the five-factor model of personality. It was expected that strength of excitation and mobility would have significant positive correlations with extraversion and negative correlations with neuroticism, while strength of inhibition would show significant negative correlations with neuroticism. Within two studies $\left(N_{1}=74\right.$ female students, $M_{\text {age }}=22 ; N_{2}=54$ female students, $\left.M_{\text {age }}=20\right)$, Croatian version of PTS, Five-Factor Nonverbal Personality Questionnaire FF-NPQ, and Eysenck's Personality Questionnaire EPQ R/A were used. The reliability coefficients for all three instruments were satisfactory, although not very high. Coefficients of correlation determined in the first study were not entirely in agreement with either theoretical expectations or empirical results of other authors, probably due to small sample size. However, the results of the second study were in accord with the expected pattern of significant correlations and that could be considered an indicator of good construct validity of PTS. Since this was a preliminary study the results provide only a general insight into the research aim, and represent a good starting point for future validation studies of the Croatian version of PTS.
\end{abstract}

Key words: construct validity, Pavlovian Temperament Survey, Five-Factor Nonverbal Personality Questionnaire, Eysenck’s Personality questionnaire, students

\section{Konstruktna veljavnost hrvaške priredbe Vprašalnika temperamenta po Pavlovu}

\author{
Sanja Tatalović Vorkapić1 ${ }^{1}$ Ivana Lučev² in Meri Tadinac ${ }^{3}$ \\ ${ }^{1}$ Faculty of Teacher Education, Department of Preschool Education, Rijeka, Croatia \\ ${ }^{2}$ Institute for Migration and Ethnic Studies, Zagreb, Croatia \\ ${ }^{3}$ Department of Psychology, University of Zagreb Faculty of Humanities and Social Science, Zagreb, Croatia
}

Povzetek: Namen raziskave je bil oceniti konstruktno veljavnost hrvaške različice Vprašalnika temperamenta po Pavlovu (VTP), in sicer s preučitvijo odnosa med tremi dimenzijami temperamenta in dimenzijami osebnosti, kot jih je definiral Eysenck, ter dimenzijah osebnosti po modelu velikih pet. Na osnovi teorije smo pričakovali, da bosta moč ekscitacije in mobilnost imeli pozitivni korelaciji z ekstravertnostjo ter negativne korelacije z nevroticizmom, medtem ko naj bi dosežek na lestvici moč inhibicije negativno koreliral z nevroticizmom. V prvi raziskavi je sodelovalo 74 študentk (povprečna starost je znašala 22 let), v drugi raziskavi pa 54 študentk (povprečna starost je znašala 20 let). Poleg hrvaške različice VTP so udeleženke izpolnile tudi pet-faktorski neverbalni vprašalnik osebnosti (FF-NPQ) ter Eysenckov vprašalnik osebnosti (EPQ$\mathrm{R} / \mathrm{A}$ ). Zanesljivost lestvic vseh uporabljenih inštrumentov je bila sprejemljiva. Korelacije med dimenzijami temperamenta in osebnosti v prvi raziskavi se v večini primerov niso prilegale teoretsko osnovanim pričakovanjem in rezultatom sorodnih raziskav. Ta rezultat je najverjetneje posledica majhnosti uporabljenega vzorca. V drugi raziskavi je vzorec korelacij ustrezal pričakovanjem, kar kaže na sprejemljivo konstruktno veljavnost hrvaške različice VTP. Pričujoča raziskava je preliminarne narave, zato rezultati predstavljajo zgolj dobro izhodišče za prihodnje validacisjke raziskave hrvašle različice VPT.

Ključne beside: konstruktna veljavnost, Vprašalnika temperamenta po Pavlovu, Pet faktorski neverbalni vprašalnik osebnosti, Eysenck vprašalnik osebnosti, študenti

\footnotetext{
${ }^{*}$ Naslov/Address: Sanja Tatalović Vorkapić, PhD, Faculty of Teacher Education, Department of Preschool Education, University of Rijeka, Slavka Krautzeka bb, 51000 Rijeka; e-mail: sanjatv@ufri.hr
}

Članek je licenciran pod pogoji Creative Commons Attribution 4.0 licence. / The article is licensed under a Creative Commons Attribution 4.0 International License. 
The Pavlovian Temperament Survey (PTS) was constructed for cross-cultural comparison of the Pavlovian dimensions of temperament and it consists of three subscales: Strength of Excitation (SE), measuring the efficiency in conditions of high levels of stimulation and preference for such situations; Strength of Inhibition (SI), referring to the ability to stop or delay a given behaviour and to refrain from certain behaviours and reactions when required; and Mobility (MO), measuring the ability to quickly and adequately react to changes in the environment (Strelau, 1983).

Temperament refers to stylistic, formal behavioural characteristics (such as typical intensity with which individual reacts). These relatively stable individual differences manifest early in life, occur in animals as well as humans and are largely biologically determined. Majority of authors agree that temperament can be mostly attributed to genetic factors (see Buss \& Plomin, 1984; Strelau, 1983; Zuckerman, 1991). Temperament traits are considered universal for all human beings regardless of their specific cultural environment (Strelau, Angleitner, \& Newberry, 1999). However, behaviours in which these dimensions manifest can be, and indeed often are somewhat culturally specific. Cross-cultural studies in psychology often encompass two basic goals: describing specificity of psychological phenomena or behaviour depending on the cultural conditions (the emic approach) and determining similarities of psychological phenomena in different cultures (the etic approach).

In order to obtain valid measures of universal temperament dimensions that would include items that refer to behaviours relevant for expression of temperament traits in particular language and culture, Strelau and his colleagues (1999) devised specific process for construction of different language versions of Pavlovian temperament survey. Definitional components that refer to different aspects of the three PTS scales were determined: 7 for SE (such as "The individual is prone to undertake activity under highly stimulating conditions" and "Under conditions of high stimulative value, the individuals performance does not decrease significantly") and 5 each for SI ("The individual easily refrains from behaviour which for social reasons is not expected or desired" and "If circumstances require, the individual is able to delay his/her reaction to acting stimuli"), and MO scale ("The individual reacts adequately to unexpected changes in the environment", "The individual prefers situations which require him/her to perform different activities simultaneously"). These definitional components were starting point for generating universal pool of items. For each new language version of PTS universal item pool of 252 items is translated and administered to a sufficiently large sample of participants $(N>400)$. Then items that most coherently represent PTS dimensions are selected for the final version. The etic approach reflects in universal facets of scales and universal item pool which presents a basis for all versions of PTS, while process of selecting items that are the most representative for universal temperament dimensions in a given culture comprises the emic approach.

Croatian version of the PTS was constructed in 2002 (Lučev, Tadinac-Babić, \& Tatalović, 2002). It consists of 69 items (23 for each dimension) and represents all of the defining components of the PTS. Total of 414 participants (134 males and 280 females), students of Universities in Zagreb and Rijeka, their family and friends were included in the construction sample. Age span of participants was between 16 and $85(M=22)$. Validation sample consisted of 101 male and 362 female university and high school students from Zagreb and Rijeka, 17-26 years old $(M=18)$ (Lučev, Tadinac, \& Tatalović Vorkapić, 2006).

Cronbach $\alpha$ coefficients determined in the construction and validation study were $\alpha_{\mathrm{SE}}=.87, \alpha_{\mathrm{SI}}$ $=.81, \alpha_{\mathrm{MO}}=.88$, and $\alpha_{\mathrm{SE}}=.80, \alpha_{\mathrm{SI}}=.79, \alpha_{\mathrm{MO}}=.83$, respectively (Lučev et al., 2002; Lučev et al., 2006). Reliability of PTS scales determined in other studies with Croatian samples was also acceptable, Cronbach $\alpha$ coefficients were all over .75 (see Table 1), which is considered acceptable by most authors (DeVellis, 1991; Nunnally, 1978) and in the range of values attained for other language versions of the inventory (Strelau et al., 1999). In the validation study, factor analysis on the defining components of the PTS was conducted. The factor structure was comparable to those established for other versions of PTS (Bodunov, 1993) and in accordance with the theoretical concept: three oblique factors that could be interpreted as SE, SI and MO (Lučev at al., 2006).

As can be expected from Pavlov's theoretical assumptions as well as empirical studies with earlier version of inventory (STI) (Strelau, Angleitner, Bantelmann, \& Ruch, 1990) and other language versions of PTS (Newberry et al., 1997; Strelau et al., 1999), scales of Croatian version of the PTS were not orthogonal. Statistically significant correlations between PTS dimensions were found on construction and validation samples (Table 1), as well as other studies that included Croatian version of the Pavlovian temperament survey (Čekolj, 2007; Lučev, 2007).

Since different language versions of PTS vary in number of items that comprise the scales, it is not possible to directly compare results on different PTS versions. In order to compare results, scores are expressed as average per-item responses on a 4 point rating scale. Again, average scores of Croatian participants on scales of PTS (Table 1) are comparable to values obtained on construction samples for other 
Table 1. Standardized means and standard deviations for PTS scales and correlations between PTS scales obtained on different Croatian samples

\begin{tabular}{|c|c|c|c|c|c|c|c|c|}
\hline & \multirow[b]{2}{*}{$N$} & \multirow[b]{2}{*}{ Subscales } & \multirow[b]{2}{*}{$M$} & \multirow[b]{2}{*}{$S D$} & \multirow[b]{2}{*}{$\alpha$} & \multicolumn{3}{|c|}{ Correlations between scales } \\
\hline & & & & & & $r_{S E-S I}$ & $r_{S E-M O}$ & $r_{S I-M O}$ \\
\hline Construction sample & & $\mathrm{SE}$ & 2.38 & 0.40 & .87 & & & \\
\hline \multirow{2}{*}{ (Lučev et al, 2002) } & 414 & SI & 2.79 & 0.34 & .81 & $.27^{* *}$ & $.67^{* *}$ & $.21^{* *}$ \\
\hline & & MO & 2.72 & 0.41 & .88 & & & \\
\hline Validation sample & 463 & SE & 2.42 & 0.35 & .80 & & & \\
\hline \multirow{2}{*}{ (Lučev et al, 2006) } & & SI & 2.71 & 0.36 & .79 & $.30^{* *}$ & $.58^{* *}$ & $.25^{* *}$ \\
\hline & & MO & 2.79 & 0.38 & .83 & & & \\
\hline \multirow[t]{3}{*}{ Lučev, 2007} & 252 & SE & 2.53 & 0.42 & .87 & & & \\
\hline & & SI & 2.82 & 0.33 & .76 & $.13^{*}$ & $.67^{* *}$ & .07 \\
\hline & & MO & 2.76 & 0.42 & .88 & & & \\
\hline \multirow[t]{3}{*}{ Čekolj, 2007} & 332 & SE & 2.51 & 0.39 & .83 & & & \\
\hline & & SI & 2.78 & 0.34 & .77 & $.22^{* *}$ & $.64^{* *}$ & $.26^{* *}$ \\
\hline & & MO & 2.74 & 0.39 & .84 & & & \\
\hline
\end{tabular}

Note: $\mathrm{SE}=$ Strength of Excitation; $\mathrm{SI}=$ Strength of inhibition; $\mathrm{MO}=$ Mobility

${ }^{*} p<.05,{ }^{* *} p<.01$

17 language versions: mean results varied from 2.23 to 2.86 for SE, from 2.08 to 3.03 for SI and from 2.21 to 2.99 for MO scale (Bucik, 2002; Newberry et al., 1997; Strelau et al., 1999). One of the main issues with cross-cultural studies on personality and temperament concerns the equivalence of the constructs measured in different cultures (Strelau \& Angleitner, 1994). Similar psychometric properties that are found for different language versions of PTS and comparable correlations between scales indicate that parallel versions of PTS measure universal temperamental traits the way original authors of this instrument intended.

The aim of this study was to examine the construct validity of PTS. An instrument with good construct validity represents a successful operationalization of the theoretical constructs it purportedly measures. If the obtained correlations with other instruments (that are supposed to measure similar or different constructs) fit the expected pattern and are in agreement with the theoretical assumptions, it is considered evidence of the construct validity of the instrument in question. Information about construct validity was gathered for many different language versions of PTS. Since Strength of Excitation refers to the ability of nervous system to withstand high levels of stimulation and preference for such situations, it was logical to expect that people with pronounced extraversion who are talkative, assertive and energetic will also have higher levels of SE. This assumption was confirmed in many studies and with different measures of SE (STI, PTS) and Extraversion (EPQ-R, NEO-FFI, NEO-P, NEO-P-R) (Strelau et al., 1999). Significant positive correlations between $M O$ and $\mathrm{E}$ were also found by different authors (Angleitner \& Ostendorf, 1994; Strelau et al., 1999). Mobility includes subscales that refer to behaviour under changing conditions and preference for situations that demand performing different activities simultaneously, which are behaviours characteristically present in extraverts, due to their tendency to seek higher levels of excitement. As for the Strength of Inhibition, one study found a weak, but significant positive correlation between SI and Extraversion (Strelau et al., 1990). However, the interpretation of this relation remains unclear. In the meta-analysis of six studies by Strelau and his colleagues (1999) it was determined that average correlation between SI and E was not statistically significant.

Neuroticism refers to emotional instability, and one of the facets of SE relates to negative emotions: performance of activity under social and/or physical load is not evoking emotional disturbances. According to Pavlov, weak nervous system with low SE and SI typically exhibits fearfulness, which is a type of behaviour encompassed in Neuroticism (Ruch, 1992). Therefore, it is not surprising that significant negative correlations were found between Neuroticism and SE, as well as between Neuroticism and MO (Angleitner \& Ostendorf, 1994; Strelau et al., 1999), the last one probably due to high and significant correlations consistently established between SE and MO (Čekolj, 2007; Lučev et al. 2002; Lučev et al., 2006; Strelau et al., 1999). Somewhat lower but still statistically significant negative correlations were found between Neuroticism and SI on various samples (Strelau et al., 1999). This could also be explained by Pavlov's conception of weak nervous system type which, as it is dominated by fear, facilitates development of neurotic behaviour. High levels of Psychoticism, as measured by EPQ-R, 
imply poorer impulse control, and hence this trait could be expected to negatively correlate with SI, i.e. the ability to control one's behaviour. This was confirmed by the meta-analysis of eight different studies: P was significantly, although weakly, negatively related to SI, the average correlation being $r=-.18$ (Strelau et al., 1999). It is harder to speculate on relationship of Psychoticism with the other two PTS scales, although significant positive correlations between $\mathrm{SE}$ and $\mathrm{P}$ were found in some empirical studies, with average correlation of $r=.17$ reported by Strelau and his colleagues (1999). Correlations between MO and P were not statistically significant (Strelau et al., 1999).

Eysenck (1994) asserted that Agreeableness and Conscientiousness, as measured by NEO inventories, are in fact components of Psychoticism. If that was indeed so, we could expect these two dimensions to show significant correlations with SI, as Psychoticism does, but in opposite direction. Amelang and Borkenau (1982) suggested that Conscientiousness (C) was a measure of impulse control, in which case we could also expect significant correlations with SI. On the other hand, if we consider Conscientiousness as a will-to-achieve factor, as proposed by Digman and Takemoto-Chock (1981), we could expect C to significantly correlate with SE and MO. Conscientiousness, as measured by NEO inventories, refers to both impulse control and will-to-achieve, hence positive correlations with all three Pavlovian dimensions can be expected. According to Strelau and colleagues (1999) meta-analysis, Openness to experience and Conscientiousness are unrelated or only weakly positively related to SE, SI and MO (average correlation ranging from $r=.04$ to $r=.22$ ), while Agreeableness has somewhat higher positive correlation with SI $(r=.33)$. In the study with the Croatian version of PTS, on a sample of 332 adult participants, Pavlovian scales were related to EPQ dimensions. Extraversion was in significant positive correlations with SE $(r=.35)$ and MO $(r=.56)$; Neuroticism was significantly negatively correlated with all three temperament dimensions: $r=-.44$ with SE, $r=-.31$ with SI and $r=-.37$ with MO; while Psychoticism was significantly correlated with SE $(r=$ .18) and SI ( $r=-.20)$ (Čekolj, 2007). These findings are completely in accordance with both theoretical expectations and the results of earlier studies.

In this study, we decided to examine the construct validity of Croatian PTS scales by relating them to basic dimensions of personality as defined by Eysenck $(\mathrm{E}, \mathrm{P}, \mathrm{N}, \mathrm{L})$ and in the five-factor model of personality (E, N, C, A, O). It was expected that SE and MO would have significant positive correlations with Extraversion and negative correlations with Neuroticism, while SI would have a significant negative correlation with Neuroticism. Eysencks' Psychoticism should be in weak negative correlations with SI, while other three scales of NEO inventory should be weakly, if at all, correlated with PTS scales. Furthermore, we expect that scales of PTS will be in statistically significant inter correlations, while levels of reliability and mean results will be in the range of results attained in previous studies with different language versions of PTS.

\section{Method}

\section{Participants}

First study was conducted on a convenience sample of 74 female students from various departments of University in Rijeka (Faculty of Teacher Education, Psychology, Languages, Mathematics, Physics, Information Technology), with average age of 22 . Second study included a sample of 54 female psychology students, with average age of 20 , recruited from the other study.

\section{Instruments}

In the first study, Pavlovian temperament dimensions were assessed with Croatian version of PTS (Lučev et al., 2002), while five basic dimensions of personality were measured by Five-Factor Nonverbal Personality Questionnaire, FF-NPQ (Paunonen, Ashton, \& Jackson, 2001), i.e. its Croatian adaptation (Tatalović Vorkapić, Lučev, \& Morosini Turčinović, 2007). As was described earlier, 69-item PTS measures three central nervous system (CNS) dimensions. Typical item of the Strength of excitation subscale is: "I like very demanding jobs"; for Strength of inhibition subscale: "I can hide my anger if needed"; and for Mobility subscale: "When my job changes, I'm quick to adjust". Subjects rated their agreement with the PTS-items using Likert's 5-point scale (from 1 - totally disagree to 5 - totally agree). The FF-NPQ consists of 60 nonverbal items presented as illustrations in Picture Booklet (for more details see Tatalović Vorkapić et al., 2007). It measures five factors, each with 12 items: Extraversion, Agreeableness, Conscientiousness, Openness to experience, and Neuroticism. All subjects were instructed to look at each illustration and to rate the likelihood of engaging in the type of behaviour shown at the picture. Seven-point Likert scale was used for ratings (ranging from 1 - extremely unlikely that I would to perform this type of behaviour to 7 extremely likely that I would to perform this type of behaviour).

In the second study subjects completed PTS as well as EPQ R/A, which measures personality dimensions as defined in Eysenck's theory (Eysenck \& Eysenck, 1994). Eysenck's Personality Questionnaire - Revised 
version is used to measure the levels of extraversion, neuroticism, psychoticism and social desirability. This instrument consists of 106 items: 23 items in the Extraversion subscale (item example: "Do you have many friends?"); 32 items in the Psychoticism subscale (item example: "Do you enjoy to insult people who you love?"); 24 items comprising the Neuroticism subscale (item example: "Have you often felt guilty?"); and 21 items that make up the Social conformity subscale (item example: "Have you ever damaged or lost others stuff?”). Participants answered to EPQ$\mathrm{R}$ items with YES or NO. Sum of answers on each EPQ-subscale indicate the position of the individual on the corresponding personality dimension.

\section{Procedure}

Participants were approached during their usual classes and they were familiar with the aim of this study, i.e. the validation of different personality dimensions questionnaires. All subjects participated voluntarily and they received course credit. Students were asked to complete the questionnaires answering sincerely and informed that the data will be used in research purposes only. Since both studies included convenience samples, only female subjects participated, homogenous by age and study programs, as well as their academic interests. Considering that, it is important to notice that this validation study has significant limitations and its findings need to be further verified. In addition, data from the second study was collected as a part of study on relationship between evoked potentials and questionnaire measures of personality and temperament. Therefore, data presented in this report are the result of the first study that examined construct validity of PTS in Croatia and should be considered an interesting starting point for the future relevant studies in this field.

\section{Results}

\section{Descriptive statistics}

Reliability coefficients for all three instruments used in this research were satisfactory, although not very high. Cronbach alpha reliability coefficients (and their lower bounds of $95 \%$ confidence interval) for PTS scales in the first study were $\alpha=.82(.77)$ for SE, $\alpha=$ .66 (.56) for SI and $\alpha=.78$ (.72) for MO scale, while the coefficients determined in the second study were $\alpha=.86(.81)$ for SE, $\alpha=.78$ (.70) for SI and $\alpha=.89$ (.85) for MO scale. Except for reliability for SI and MO scale found in first study, values were in the range of findings reported for 16 different language versions of PTS (Strelau et al., 1999). According to Nunnally and Bernstein (1994) satisfactory level of reliability for instruments used in early stages of construct validation research is about .70 or higher, while they consider increasing reliabilities much beyond .80 is a waste of time with instruments used for basic research. Therefore, all of the reliability coefficients (and their assessed lower bounds) determined for instruments used in the two studies were adequate except for reliability of SI scale found in the first study which was somewhat lower.

Strelau and his colleagues (1999) reported lower average reliability, as well as larger variance in values of reliability coefficients for different language versions of SI scale, and Strelau suggested this could be explained by the fact that SI scale was more saturated by cultural factors than MO or SE. Some of the items that indicate low levels of SI might be under greater influence of social desirability than others. For instance, admitting to "It is hard for me to control my curiosity when I have the chance to look at someone else's things or notes" is probably less desirable than agree with statement "It is difficult for me to interrupt

Table 2. Descriptives for PTS subscales (SE = Strenght of excitation, SI = Strenght of inhibition, MO = Mobility) and FF-NPQ subscales (Extraversion, Agreeableness, Consciousness, Openness, Neuroticism) in the first study

\begin{tabular}{|c|c|c|c|c|c|c|}
\hline \multicolumn{2}{|c|}{ Subscales } & $M(M$ per item $)$ & $S D$ & Total range & $\begin{array}{l}\text { Skewness coefficients } \\
\text { and their } S E \text { s }\end{array}$ & $\begin{array}{l}\text { Kurtosis coefficients } \\
\text { and their } S E \text { s }\end{array}$ \\
\hline \multirow{3}{*}{$\mathscr{\omega}$} & SE & $55.37(2.41)$ & 7.89 & $38-76$ & $.29(.30)$ & $-.11(.59)$ \\
\hline & SI & $63.58(2.76)$ & 5.91 & $48-79$ & $.26(.30)$ & $.36(.59)$ \\
\hline & $\mathrm{MO}$ & $60.31(2.62)$ & 6.78 & $48-77$ & $.48(.29)$ & $-.29(.57)$ \\
\hline \multirow{5}{*}{$\begin{array}{l}O \\
Z_{1} \\
\frac{1}{1} \\
1\end{array}$} & $\mathrm{E}$ & 48.18 & 9.64 & $26-69$ & $.09(.28)$ & $-.59(.55)$ \\
\hline & A & 67.88 & 8.65 & $46-83$ & $-.52(.28)$ & $-.03(.55)$ \\
\hline & $\mathrm{C}$ & 54.52 & 9.55 & $31-82$ & $.07(.28)$ & $.50(.55)$ \\
\hline & $\mathrm{O}$ & 59.44 & 9.50 & $38-81$ & $.22(.28)$ & $.01(.55)$ \\
\hline & $\mathrm{N}$ & 47.09 & 9.70 & $22-72$ & $-.57(.28)$ & $.62(.55)$ \\
\hline
\end{tabular}


Table 3. Descriptives for PTS subscales (SE = Strength of excitation, SI = Strength of inhibition, MO = Mobility) and $E P Q-R / A$ subscales (Extraversion, Neuroticism, Psychoticism and Social Desirability) in the second study

\begin{tabular}{|c|c|c|c|c|c|c|}
\hline \multicolumn{2}{|c|}{ Subscales } & \multirow{2}{*}{$\begin{array}{l}M(M \text { per item }) \\
53.82(2.34)\end{array}$} & \multirow{2}{*}{$\begin{array}{l}S D \\
8.75\end{array}$} & \multirow{2}{*}{$\begin{array}{l}\text { Total range } \\
34-72\end{array}$} & \multirow{2}{*}{$\begin{array}{l}\text { Skewness coeffi- } \\
\text { cients and their } S E \text { s } \\
.16(.32)\end{array}$} & \multirow{2}{*}{$\begin{array}{l}\text { Kurtosis coefficients } \\
\text { and their } S E \mathrm{~s} \\
-.62(.64)\end{array}$} \\
\hline \multirow{3}{*}{$\stackrel{\mathscr{\omega}}{\omega}$} & SE & & & & & \\
\hline & SI & $65.06(2.83)$ & 6.92 & $50-82$ & $.42(.32)$ & $.02(.64)$ \\
\hline & MO & $66.24(2.88)$ & 9.41 & $45-89$ & $.34(.32)$ & $.09(.64)$ \\
\hline \multirow{4}{*}{ 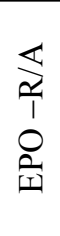 } & $\mathrm{E}$ & 15.48 & 5.44 & $1-23$ & $-.73(.32)$ & $-.34(.64)$ \\
\hline & $\mathrm{N}$ & 9.02 & 5.62 & $0-22$ & $.75(.32)$ & $-.10(.64)$ \\
\hline & $\mathrm{P}$ & 8.44 & 3.09 & $2-15$ & $-.29(.32)$ & $-.29(.64)$ \\
\hline & SD & 3.52 & 2.73 & $0-10$ & $.61(.32)$ & $-.50(.64)$ \\
\hline
\end{tabular}

something I'm doing even if someone asks me to". If this is the case, most of the participants would answer under strong influence of cultural norms and answers to such an item would reflect their true level of SI to a lesser extent. Lower levels of variability for results on SI scale compared to other two PTS scales determined in studies with different language versions of the instrument (see Strelau et al., 1999) are in accordance with this assumption. Furthermore, since SI items vary in the level of influence social desirability has on answers, correlations between items and Cronbach $\alpha$ coefficients that reflect them could be lower. Mean values, standard deviations, total ranges and results of skewness and kurtosis from the first study are presented in Table 2. Overall, the results are in accordance with the values expected based on previous studies of Pavlovian dimensions (Strelau et al., 1999) and nonverbal Five-Factor dimensions (Tatalović Vorkapić et al., 2007). Reliability and its lower bounds for different subscales of Five Factor Nonverbal Personality Questionnaire used in the first study was satisfactory: Cronbach alpha reliability coefficients for Extraversion, Agreeableness, Conscientiousness, Openness and Neuroticism were $\alpha=.78$ (.72), $\alpha=.74$ (.66), $\alpha=.84$ (.79), $\alpha=.79(.73)$ and $\alpha=.77$ (.70), respectively. All distributions are considered not to significantly deviate from normal distribution according to the skewness and kurtosis coefficients.

The reliabilities of EPQ R/A scales with their lower bounds (the second study) were also mostly within the acceptable range: values of Cronbach alpha coefficients were $\alpha=.89$ (.85) for Extraversion, $\alpha=.89$ (.85) for Neuroticism, $\alpha=.61$ (.48) for Psychoticism, and $\alpha=$ .68 (.57) for Social Desirability. Mean values, standard deviations, total ranges and skewness and kurtosis coefficients from the second study are presented in Table 3. The group average for the EPQ R/A Extraversion ( $M$ $=15.5 ; S D=5.4$ ) did not substantially differ from the one obtained on the Croatian standardization group
$(M=14.2 ; S D=4.7)$ (Eysenck \& Eysenck, 1994). All distributions are rather symmetrical (skewness results are close to zero) and at the same time are rather far from adequate kurtosis levels (far from 3).

Since different language versions of PTS consist of different number of items, the results of different versions are compared through average response per item of each scale. This value for PTS scales in the first study was 2.41 for SE, 2.76 for SI and 2.62 for MO, while the average response per item found in second study was 2.34 for SE, 2.83 for SI and 2.88 for MO. All these values do not differ substantially from those found in other studies with Croatian version of PTS (see Table 1) and are in the range of results determined in studies with different language versions of PTS (Newberry et al., 1997; Strelau et al., 1999).

Correlations between scales of PTS found in the first study were $r_{\mathrm{SE}, \mathrm{SI}}=.56, r_{\mathrm{SE}, \mathrm{MO}}=.66, r_{\mathrm{SI}, \mathrm{MO}}=.39$, while those found in the second study were $r_{\mathrm{SE}, \mathrm{SI}}=.33$, $r_{\mathrm{SE}, \mathrm{MO}}=.68, r_{\mathrm{SI}, \mathrm{MO}}=.36$.

\section{Correlation analysis}

Coefficients of correlation determined in the first study (Table 4) were not entirely in accordance with either theoretical expectations or empirical results of other authors.

Although correlations of all included personality variables were in the expected direction, the correlation between Neuroticism and SE was not significant, while some other correlations were higher than expected. This could be an accidental finding and should probably be attributed to a small number of participants and low representativeness of the samples. In the future studies with larger number of subjects, heterogeneous in age, sex and academic interests', results will probably be in accordance with expected level and direction of correlations between PTS and FF-NPQ dimensions.

Results of the second study (Table 5) were in accord 
Table 4. Correlation matrix with Pearson's correlation coefficients of PTS subscales and FF-NPQ subscales in the first study

\begin{tabular}{lllllll}
\hline \multirow{2}{*}{ Subscales } & \multicolumn{5}{c}{ FF-NPQ } \\
\cline { 2 - 6 } & $\mathrm{E}$ & $\mathrm{A}$ & $\mathrm{C}$ & $\mathrm{O}$ & $\mathrm{N}$ \\
\hline & SE & $.30^{* *}$ & $.25^{*}$ & $.30^{*}$ & $.45^{* *}$ & -.17 \\
& SI & $.28^{*}$ & $.39^{* *}$ & $.46^{* *}$ & $.51^{* *}$ & $-.28^{* *}$ \\
& MO & $.48^{* *}$ & $.38^{* *}$ & $.38^{* *}$ & $.50^{* *}$ & $-.42^{* *}$ \\
\hline
\end{tabular}

Note: $\mathrm{SE}=$ Strength of Excitation; $\mathrm{SI}=$ Strength of inhibition; $\mathrm{MO}=$ Mobility $; \mathrm{E}=$ Extraversion; $\mathrm{A}=$ Agreeableness; $\mathrm{C}=$ Consciousness; $\mathrm{O}=$ Openness; $\mathrm{N}=$ Neuroticism ${ }^{*} p<.05,{ }^{* *} p<.01$

Table 5. Correlation matrix with Pearson's correlation coefficients of PTS subscales and EPQ-R/A subscales from the second study

\begin{tabular}{cccccc}
\hline \multirow{2}{*}{ Subscales } & \multicolumn{4}{c}{ EPQ-R/A } \\
\cline { 2 - 6 } & $\mathrm{E}$ & $\mathrm{N}$ & $\mathrm{P}$ & $\mathrm{SD}$ \\
\hline \multirow{2}{*}{$\mathrm{SE}$} & $.41^{* *}$ & $-.67^{* *}$ & .19 & -.03 \\
$\mathrm{2}$ & $\mathrm{SI}$ & .16 & $-.36^{* *}$ & -.01 & .14 \\
& $\mathrm{MO}$ & $.65^{*}$ & $-.56^{* *}$ & .17 & .10 \\
\hline
\end{tabular}

Note $: \mathrm{SE}=$ Strength of Excitation; $\mathrm{SI}=$ Strength of inhibition; $\mathrm{MO}=$ Mobility; $\mathrm{E}=$ Extraversion; $\mathrm{N}=$ Neuroticism; $\mathrm{P}=$ Psychoticism; $\mathrm{SD}=$ Social desirability

${ }^{*} p<.05,{ }^{* *} p<.01$

with the expected pattern of correlations: significant positive correlations of Extraversion with both SE and MO were found, as well as significant negative correlations of Neuroticism and both SE and MO which are also consistent with theoretical predictions and empirical results of previous studies (Čekolj, 2007; Strelau et al., 1999). Overall, correlations found in the second study suggest adequate construct validity of PTS.

\section{Discussion}

Reliability coefficients for PTS scales were satisfactory, but not very high. Furthermore, all reliability coefficients, except those for SI and $\mathrm{MO}$ scale in the first study, are within the range of values found in other studies with different language versions of PTS (Corrula, Strelau, Angleitner, \& Ruch, 1993; Newberry et al., 1997; Strelau et al., 1999). Reliability determined for the SI scale is somewhat lower than for the other two scales, and one possible explanation for this rather consistent finding is that strength of inhibition is more saturated with cultural factors than strength of excitation or mobility (Strelau at al., 1999). In addition, samples that were used in both presented studies were not very large, and lower reliabilities could be expected in smaller and more homogenous samples than in the construction and standardization studies. Reliabilities determined for this instrument are usually higher, as it was shown in the construction sample for Croatian version of PTS ( $\alpha=.87$ for SE, $\alpha=$ .81 for SI and $\alpha=.88$ for MO scale; Lučev et al., 2002), as well as on the validation sample of 463 participants, and in other studies using the Croatian PTS scales: values of $\alpha$ ranged from .80 to .87 for $\mathrm{SE}$, from .76 to .79 for SI and from .83 to .88 for MO (Čekolj, 2007; Lučev et al., 2006; Lučev, 2007).

Average results on PTS scales from the first study are presented in Table 2 and those from the second study in Table 3. These findings are in accordance with both the results of previous research using the Croatian PTS and average results per item found for other versions of PTS (Čekolj, 2007; Lučev et al., 2006; Lučev, 2007; Newberry et al., 1997; Strelau et al., 1999).

Due to specific process of construction of new language versions of PTS, different versions vary in number of items and in actual items that comprise the final version of the instrument. Comparable levels of reliability found for different language versions of PTS as well as similar values of average results on subscales and correlations between dimensions of temperament can be considered an indicator of acceptable validity. It could be concluded that parallel versions of PTS are measuring the same cross-culturally universal dimensions of temperament the way original authors of instrument intended.

Correlations between scales of PTS found in the first study were $r_{\mathrm{SE}, \mathrm{SI}}=.56, r_{\mathrm{SE}, \mathrm{MO}}=.66, r_{\mathrm{SI}, \mathrm{MO}}=.39$, while those found in the second study were $r_{\mathrm{SE}, \mathrm{SI}}=.33$, $r_{\mathrm{SE}, \mathrm{MO}}=.68, r_{\mathrm{SI}, \mathrm{MO}}=.36$. As mentioned earlier, lack of orthogonality is expected for Pavlovian dimensions and determined values are in accordance with theoretical expectations and results of other studies with PTS, although some of them are slightly higher than the range of values reported by other authors (Strelau et al., 1999). Correlations between SE and SI determined for 16 different language versions of PTS vary from statistically insignificant to .46 , with average of $r=.25$, correlations between SE and MO vary from .30 to .64 with average coefficient of $r=.52$, while correlations between SI and MO vary from statistically insignificant to .40 , with average of $r=.21$ (Strelau et al., 1999). In four previous studies with Croatian version of PTS values of correlation between $\mathrm{SE}$ and $\mathrm{MO}$ scale that were determined were quite large (see Table 1), and in three studies (Čekolj, 2007; Lučev et al., 2002; Lučev, 2007) values were as high or a little higher than the largest SE-MO inter-correlation reported by Strelau et al. (1999). Correlation coefficients between SE and MO scale found in two studies presented here are in accord 
with general expectations of positive relationship between these dimensions and comparable to values determined on Croatian samples (in the case of the second study, inter-correlation is just a little, but not significantly higher than in previous studies), if a little higher than values found for other versions of PTS. Correlations between SI and MO scale and between SE and SI found in second study are well in the range of results of earlier studies (Čekolj, 2007; Lučev et al., 2002; Lučev et al., 2006; Strelau et al., 1999), while value of SE and SI correlation found in the first study is quite unusually high, and could probably be considered an accidental finding due to small and homogenous sample of participants.

Coefficients of correlation between PTS scales and FF-NPQ (Table 4) are all in the theoretically expected direction, but their values do not entirely confirm the assumptions based on theory and results of other authors. As expected, SE and MO showed significant positive correlations with Extraversion, and $\mathrm{MO}$ was negatively correlated with Neuroticism. It is not surprising that extraverted people, who are sociable, energetic, assertive, and prefer high levels of excitement have higher scores on SE - scale that measures self-professed ability to withstand intense or prolonged stimulation and preference for risky behaviours and situations with high levels of stimulation. It is also not surprising that Extraverts show more pronounced ability to adequately and quickly react to unexpected changes in environment, adaptability to new environment and preference for engaging in number of different activities simultaneously, behaviours that Mobility scale refers too. Individuals with pronounced Neuroticism are prone to negative emotions, such as fear, sadness and anger, and they react poorly to stress. Therefore, they are probably less capable of quick adaptation to unexpected changes, so it is not surprising they have lower results on MO. Strelau and his colleagues (1999) attribute relationship between $\mathrm{N}$ and MO to the close link between MO and SE. These results are also in accordance with previous studies on different versions of PTS (Angleitner \& Ostendorf, 1994; Strelau et al., 1999).

On the other hand, the correlation between SE and Neuroticism did not reach the level of statistical significance in the second study. There is a big discrepancy in values of SE- $\mathrm{N}$ correlation found in two presented studies $(-0.67$ vs. -0.17$)$. This might be attributed to somewhat different conceptualisation of the Neuroticism dimension by Eysenck, and within the Big Five as a dimension of Emotional stability. Eysenck's theory is more neuropsychologicaly grounded, similar to PTS-dimensions that Pavlov defined as properties of the central nervous system. On the other hand, FF-NPQ has its roots in the lexical approach to personality research that was aimed to create the descriptive taxonomy (John, Angleitner, \& Ostendorf, 1988). It was initially based on the analysis of the natural language terms people usually use to describe themselves and others, and this resulted in dimensions of human personality that are not as directly conceptually linked to underlying autonomic nervous system changes. SI had significant negative correlations with Neuroticism, which is in accordance with predictions. Pavlov (Strelau et al., 1999) considered that an individual with weak type of nervous system, who has low SE as well as SI, is fearful and promotes development of neurotic behaviours.

However, SI also had significant positive correlations with Openness, Agreeableness, Conscientiousness, and Extraversion, which were not expected. SE and MO had statistically significant positive correlations with Conscientiousness, Agreeableness, and Openness. SI and Extraversion correlated positively, which could be attributed to the fact that $\mathrm{SE}$ and $\mathrm{E}$ have positive correlation, while SI is significantly related to both other Pavlovian dimensions. These unexpected findings could be explained by somewhat "unclear" factor structure of the instrument (16 items had high loadings on two or more factors), which was probably due to different interpretation and understanding of nonverbal items presented to subjects. Five factors that were kept in the final solution explained $33.9 \%$ of total variance, which is a relatively small percentage of explained variance (Tatalović Vorkapić et al., 2007). To summarize, in the future research on construct validity of the PTS it would be necessary to include personality measures with better psychometric properties.

As for Agreeableness, similar values of positive correlations with SI were found in meta-analysis of six studies (Strelau et al., 1999). It is logical for a trait such as Agreeableness (tendency to be pleasant, cooperative, considerate, friendly and helpful) to be positively related to ability to control one's behaviour. Some studies report significant positive correlations between SE, MO and Openness (Angleitner \& Ostendorf, 1994). However, according to meta-analysis of Strelau and his colleagues (1999), Openness to experience and Conscientiousness were unrelated or only weakly positively related to SE, SI and MO, with average correlation from $r=.04$ to $r=.22$, while in our study the values of these correlations were much higher (Table 4). A possible explanation for somewhat unexpected results could be a relatively small sample of participants that consisted of only female subjects (Tatalović Vorkapić et al., 2007). Future studies with a larger number of participants, heterogonous by gender, age and academic/vocational interests could provide a better insight into the real nature of correlations between PTS and FF-NPQ dimensions. 
In the second study, we related Pavlovian Temperament Survey to EPQ-R dimensions, and results (Table 5) confirmed the expected pattern of correlations. Correlations between SE, MO and Extraversion were statistically significant and positive, while Neuroticism was significantly negatively correlated with all PTS-dimensions. These results confirm empirical findings of other authors (Čekolj, 2007; Strelau et al., 1999). We discussed the nature of relationship between Extraversion and PTS scales in detail earlier in the paper. Neuroticism refers to tendency towards negative emotions such as fear and sadness. As we already stated, Pavlov considered that individuals with a weak nervous system have low SE, SI and MO and such individuals are typically fearful, less capable of adaptation to changing situations, high levels of stimuli or of controlling one's behaviour and emotions, and therefore prone to development of neurotic behaviour.

Since high levels of Psychoticism, as measured by EPQ-R, imply poorer impulse control, it could be expected for this trait to have negative correlations with SI. Strelau and his colleagues (1999) confirmed this hypothesis in their meta-analysis of eight different studies: P was significantly, although weakly negatively related to SI, with average correlation of $r=-.18$. In our study, we obtained negative coefficient of correlation between $\mathrm{P}$ and SI, but it was not statistically significant (see Table 5). It is possible that this was due to a relatively small sample of participants.

Nevertheless, results of the second study were mostly in accordance with theoretical expectations and conclusions of previous studies. Correlations between PTS and EPQ-R/A scales indicate that these instruments share a part of the subject they measure. However, measures of temperament, in this case Pavlovian Temperament Survey, provide valuable information on individual differences that are not covered by Eysenck's EPQ or Big Five personality dimensions. Although samples used in our two studies were relatively small, we decided to present the results as preliminary findings on the construct validity of the Croatian version of PTS, and as a contribution to the growing body of knowledge on psychometric properties of PTS.

\section{Conclusion}

Mean values and Cronbach alpha reliability coefficients for all three scales of Croatian version of Pavlovian Temperament Survey were within the range of values determined in other studies using PTS. Results of this study indicate a satisfactory validity of the PTS. The reliability of all three PTS scales was adequate, and correlations with Eysenck's and Big Five personality dimensions were mostly in accordance with theoretical assumptions as well as with the results of other similar studies. Since this study has one great limitation, namely the use of samples that consist of a small number of only female students, who were homogenous by age and academic interests, the results of this study do not permit us to make any generalized conclusions. This research was a preliminary study of the construct validity of PTS and can serve as a good starting point for future validation studies of this instrument.

\section{References}

Angleitner, A., \& Ostendorf, F. (1994). Temperament and the Big-Five factors of personality. In C. F. Halverson Jr., G. A. Kohnstamm, \& R. P. Martin (Eds.), The developing structure of temperament and personality from infancy to adulthood (pp. 69-90). Hillsdale, NJ: Erlbaum.

Amelang, M., \& Borkenau, P. (1982). Über die faktorielle Struktur und externe Validität einiger Fragebogen-Skalen zur Erfassung von Dimensionen der Extraversion und emotionalen Labilität [On the factorial structure and external validity of some questionnaire scales assesing the dimensions extraversion and emotional lability]. Zeitschrift für Differentielle und Diagnostische Psychologie, 3, 119-146.

Bucik, V. (2002). Psychological instrument in cross-cultural perspective: the case of the Pavlovian Temperament Survey. Prispevek, predstavljen na srečanju 5. Wissenhäftliche Tagung der Österreichichen Gesellschaft für Psychologie. Wien, Austria.

Bodunov, M. V. (1993). Factor structure of the Pavlovian Temperament Survey in a Russian population: Comparison and preliminary findings. Personality and Individual Differences, 14, 557-563.

Buss, A. H., \& Plomin, R. (1984). Temperament. Early developing personality traits. Hillsdale, NJ: Erlbaum.

Corrula, W. J., Strelau, J., Angleitner, A., \& Ruch, W. (1993). The developement of the Revised Pavlovian Temperament Survey in England: Continuing research. Personality and Individual Differences, 14, $323-328$.

Čekolj, T. (2007). Usporedba Eysenckove i Pavlovljeve tipologije temperamenta [Comparison of Eysenck's and Pavlovian typology of temperament]. Unpublished manuscript, Department of Psychology, University of Zagreb, Zagreb, Croatia.

DeVellis, R. F. (1991). Scale development. Newbury Park, NJ: Sage Publications.

Digman, J. M., \& Takemoto-Chock, N. K. (1981). Factors in the natural language of personality: Re-analysis comparison, and interpretation of six major studies. Multivariate Behavioral Research, 16, 149-170.

Eysenck, H. J. (1994). The Big Five or Giant Three: Criteria for a paradigm. In C. F. Halverson, G. A. Kohnstamm \& R. P. Martin (Eds.), The developing structure of temperament and personality from infancy to adulthood (pp. 37-51). Hillsdale, NJ: Erlbaum. 
Eysenck, H. J., \& Eysenck, S. B. G. (1994). Priručnik za Eysenckove skale ličnosti: EPS-odrasli [Manual for Eysenck Personality Scales: EPS - adults]. Jastrebarsko, Croatia: Naklada Slap.

John, O. P., Angleitner, A., \& Ostendorf, F. (1988). The lexical approach to personality: A historical review of trait taxonomic research. European Journal of Personality, 2, 171-203.

Lučev, I. (2007). Subjective quality of life, objective quality of life measures, demographic and psychological variables (Unpublished master's thesis). University of Zagreb, Zagreb, Croatia.

Lučev, I., Tadinac-Babić, M., \& Tatalović, S. (2002). Konstrukcija hrvatske verzije Pavlovijanskog upitnika temperamenta (PTS) [Construction of the Croatian version of the Pavlovian Temperament Survey (PTS)]. Suvremena psihologija, 5(2), 207-226.

Lučev, I., Tadinac, M., \& Tatalović Vorkapić, S. (2006). Krosvalidacija hrvatske verzije Pavlovijanskog upitnika temperamenta (PTS) [Crossvalidation of the Croatian version of Pavlovian Temperament Survey (PTS)]. Suvremena psihologija, 9(1), 35-45.

Newberry, B. H., Clark, W. B., Crawford, R. L., Strelau, J., Angleitner, A., Hollinger Jones, J., \& Eliasz, A. (1997). An American English version of the Pavlovian Temperament Survey. Personality and Individual Differences, 22(1), 105-114.

Nunnally, J. C. (1978). Psychometric theory. New York, NY: McGraw-Hill.

Nunnally, J. C., \& Bernstein, I. H. (1994). Psychometric theory. New York, NY: McGraw-Hill.

Paunonen, S. V., Ashton, M. C., \& Jackson, D. N. (2001). Nonverbal assessment of the Big Five personality factors. European Journal of Personality, 15(1), 3-18.

Ruch, W. (1992). Pavlov's types of nervous system, Eysenck's typology and the Hippocrates-Galen temperaments: An empirical examination of the asserted correspondence of three temperament typologies. Personality and Individual Differences, 13(12), 1259-1271.

Strelau, J. (1983). Temperament, personality, activity. London: Academic Press.

Strelau, J., Angleitner, A., Bantelmann, J., \& Ruch, W. (1990). The Strelau Temperament Inventory - Revised (STI-R): Theoretical considerations and scale development. European Journal of Personality, 4, 209-235.

Strelau, J., \& Angleitner, A. (1994). Cross-cultural studies on temperament: Theoretical considerations and empirical studies based on the Pavlovian Temperament Survey (PTS). Personality and Individual Differences, 16, 331-342.

Strelau, J., Angleitner, A., \& Newberry, B. H. (1999). The Pavlovian Temperament Survey (PTS): An international handbook. Göttingen, Germany: Hoegrefe \& Huber Publishers.

Tatalović Vorkapić, S., Lučev, I., \& Morosini Turčinović, S. (2007). Factor analysis of FF-NPQ used on Croatian sample. In V. Ćubela Adorić (Ed.), Book of selected proceedings: 15th psychology days in Zadar, $25^{\text {th }}-27^{\text {th }}$ May 2006 (pp. 385-397). Zadar, Croatia: University of Zadar.

Zuckerman, M. (1991). Psychobiology of personality. Cambridge, UK: Cambridge University Press. 